\title{
The implementation of CSR in the extractive industries in Indonesia: What is the government's role?
}

\author{
Anif Fatma Chawa \\ Departement of Sociology at Faculty of Social and Poitical Science, Universitas \\ Brawijaya, Indonesia \\ anif.chawa@gmail.com
}

\begin{abstract}
This article aims to illustrate the role of government in the implementation of CSR in the extractive industries. The extractive industries need support from the government to resolve various problems which have emerged in conducting their CSR. These problems have arisen because of the contradiction and tension in the role or framework of business communities of the extractive industries, as an economic and social agent. To address those problems, based on a structural functional perspective, the extractive industries need other institution primarily government to establish policies or regulations in conducting their CSR. This study employs systemic review method reviewing 70 journal articles of research studies which focus on the implementation of CSR in the extractive industries in Indonesia. This study found that government has an important role to stipulate several regulations mostly at a national level. The regulations require the extractive industries to implement CSR to specifically address various negative impacts, socially, culturally and environmentally, on the affected communities. This study, however, also found that there is insufficient guideline at a local level in relation to CSR. Consequently, the extractive industries have no guidelines in how to establish their CSR activities, to what extend they should involve the local communities as well as the local governments in these activities and to address various problems which have emerged in the implementation of CSR. The lack of guidelines has also given rise to the different perception of the local governments on how they should be involved in the implementation of CSR.
\end{abstract}

Keywords. CSR, extractive industries, government

\section{Introduction}

The extractive industries have taken a 'greedy monster' attitude in exploiting natural resources. They neglect social legitimacy while causing severe negative impacts on local communities and environment. Moreover, the positive impacts of CSR (Corporate Social Responsibility) activities in this kind of industry have been questioned. There is little evidence that these activities have contributed to minimize negative impacts of the exploitation, let alone addressing sustainable development issues. As a consequence, potentially local community could not obtain maximum benefit from the extractive industries and would continuously depend on these industries, particularly after these industries are ceased (Jenkins \& Obara, 2008). Moreover, research studies also demonstrates that most of the extractive industries have manipulated CSR initiatives and community development programs to attain practical reasons 
including maintain a public image as good corporate citizens (Coronado \& Fallon, 2010; Ballard, 2001) and obtain social legitimacy to continue to operate (Coronado \& Fallon, 2010).

The problems in the implementation of CSR have emerged due to the fact that there is two contradictory frameworks, the production/commercial oriented framework and the development agenda, which should be conducted by the business communities in conducting their CSR or community development programs (Kemp, 2010). There are many research studies which have explored the problems emerge in the implementation of CSR in extractive industries, including oil, gas and mining industries (Ballard, 2001; Coronado \& Fallon, 2010; Frynas, 2005; Jenkins \& Obara, 2008; Muller, 2006; Sarin, Reisch, Kalafut, \& Slack, 2006; Ramasastry, 2015; Kolk, 2016; Lesaffer, Ghys, Nguyen, \& Rouchon, 2011). Mostly, these studies explore particular issues including human rights, environment, ethic, the impacts on community, and conflicts etc. These studies, however, have placed the extractive industries vis a vis the local communities. Studies concerning on the government's involvement in the implementation of CSR are still scarce. Newell and Frynas (2007) stated that business communities including mining industries acquire many supports from civil society and the state or government in conducting CSR (Newell \& Frynas, 2007). Newell and Frynas continues to explain that the state or government should become the key actor who responsible for determining the policies or regulations to address the complexity of the CSR or community development programs. Based on this assumption, this study aims to explore the involvement of the to obtain the effectiveness of the CSR or community development implementation in the mining industry area.

\section{Research Methods}

This study employs qualitative systematic review method to fully capture the complexity of problems and issues in the implementation of CSR by extractive industries in Indonesia. Systemic Review is a research method to identify, evaluate, and interpret certain topics or issues of research studies (Kitchenham, 2004). Kitchenham (2004) explained further that systemic review is a secondary study which attempts to make synthesis of various research studies. The result of this study potentially give equal and comprehesive facts to decision makers.

Francis and Baldesari (2006) in Siswanto (2010) stated that there are several steps to conduct systemic review method (2006). First, formulating research question which is to what extend government has been involved in the implementation of CSR or community development programs in extractive industries in Indonesia. Second, conducting a systematic literature search. In this study, secondary data was collected from seventy (70) qualitative research studies which have been published in various journal articles which focus on the CSR activities of extractive industries in several provinces of Indonesia. Third, screening and selecting appropriate research articles. From seventy journal articles, this study selected articles with qualitative method and focus on the involvement of government in CSR activities of the extractive industries. Fourth, analyzing and synthesizing qualitative findings. Fifth, maintaining quality control. Sixth, presenting findings.

On analyzing and synthesizing data, this study employs meta-synthesize which is synthesize technique of data to obtain new concept and theory or to attain in depth and comprehensive understanding (Perry \& Hammond, 2002). Meta-synthesize has two approaches which are meta-aggregation and meta-ethnography (Lewin, 2008). In particular, this study employs meta-aggregation approach to synthesize data research by summarizing various results studies in relation to the involvement of government in the CSR's mining companies. In doing so, first this study elaborates the research topic in several themes to create conceptual framework. This study focuses on four themes including the involvement of government in the 
CSR initiatives, the local community participation, to what extend the extractive industries have conducted their CSR activities and the impact of these activities on the affected communities. Then, the journal articles were collected based on these themes to be synthesized and compared. The result of these processes is an aggregate of research studies in relation to the themes. This study focuses more on the government's involvement in the implementation of CSR in the extractive industries.

\section{Literature Review}

\section{Addressing Two Contradictions and Tension Agendas of Business Communities}

Corporate Social Responsibility (CSR) is relevant to extractive industry concerning various negative impacts of the industry upon economic, social and environment. Several research studies have documented these effects in different countries including Russia, Suriname, the Philippines, Ghana, and Indonesia. Access to land issues at the exploration and mining stages, environmental degradation, conflicts between the mining companies and communities, the destruction of local communities, and human rights violations are some of the negative impacts which have occurred in these countries (Hilson \& Murck, 2001; Ballard, 2001; MacKay, 2002; Korsah-Brown, 2002; MacKay, 2002; Rosenthal, 2002; Martin \& Newell, 2008; Yakovleva, 2005; Lesaffer, Ghys, Nguyen, \& Rouchon, 2011; Kolk, 2016). Therefore, the implementation of CSR or community development program has been assumed would address all the negative impacts caused by mining operations.

The implementation of CSR means that business communities are expected to fulfil a new role as a social agent in relation to their internal and external environment including the society or communities in the local area (Wartick \& Wood 1998; Wood 1994). As social agent, business should be responsible to bring prosperity to the communities. This role is different from the central role of business as an economic institution which is to obtain profit and increase production. The role of business as a social agent ethically has emerged based on the issues concerning the negative impacts of business or corporate activities on the community. Consequently, business has expanded their involvement addressing various development problems, such as poverty; social exclusion based on gender, race, ethnicity and class inequality; social justice and other development challenges (Newell \& Frynas 2007).

The role shifting of business communities to give more contribution on communities have raised questions with regard to the capability or effectiveness and also the limitations of business to conduct development programs as part of their CSR. Kemp (2010) argued that there is contradiction and tension between two different roles or framework of business communities. This tension has caused discrepancy of opinion among scholars. The groups, including the United Nations (UN) and the World Bank who favor CSR believe in the positive contribution of business to economic and human development and affirm the CSR potential to alleviate poverty. In particular, in relation to the extractive industries which are examined in this study, CSR or community development is still believed to be the best solution to ensure the local community will directly benefit from these industries activities (Davidson \& Braithwaite 2005).

Conversely, other groups who refuse the idea of CSR always question the capability of business communities to reconcile two opposite objectives, both economic and social responsibility agendas. They have criticized the implementation of CSR as unrealistic and as purely for public relations reasons (Blowfield 2004; Kemp, D 2010; Newell \& Frynas 2007). Kemp (2010) continues to question: to what degree can a mining industry privilege the interests of the poor and marginalized over the company's own interests? The skepticism about the 
involvement of business in development programs has emerged since the objective to achieve greater production and profit is more dominant than the aim to contribute to the development programs for community betterment through CSR (Blowfield 2004; Cragg 2002; Fox 2004; Hamann, R 2003; Harcourt 2004; Kapelus 2002; Kemp, D 2010; Leisinger 2007; Newell \& Frynas 2007; Utting 2007; Wartick \& Wood 1998).

Moreover, the pessimism in relation to double frameworks of business communities can be traced back from the history of CSR. Historically, the increasing social role of business in development is 'linked both to the declining confidence of the government as an agent for development and to global deregulation from the 1980s resulting in a more limited role for the government in the economy' (Newell \& Frynas 2007, p. 672). This role is associated with the capability of government or state to provide public services including the provision of basic infrastructure and enabling access to water, electricity, health and education. Due to this shift, businesses now have a multitude of roles including as investors, providers of goods and services, creators of development policies, and as providers of basic infrastructure. Furthermore, they are challenged to tackle development problems, particularly poverty alleviation.

Arguably, the role of business communities as a development agent is very complex. They are expected to 'replace' the obligation of government to deliver development programs to society. Furthermore, CSR or community development activities would be challenged by various problems which emerge due to the fact that the business communities are having direct interactions with local communities. Therefore, business communities cannot solely contribute to development programs without any support from civil society and the government. The government is responsible for determining the policies or regulations to address the complexity of development problems, which inherently will involve social and political factors (Newell \& Frynas 2007). The government has a role in constituting and continuing to set the terms and conditions for the role of business in their country's own development, through systems of incentives and disincentives provided through regulation, tax and the like. Therefore, rights and responsibilities of investors and communities will be determined.

The involvement of NGOs, government and business communities in the implementation of CSR can be viewed from a structural functionalist perspective (Newell \& Frynas, 2007). According to this perspective, societies contain interdependent structures, each of which performs certain functions for the maintenance of society; the function of one structure will need the function or existence of another structure in order to achieve stability, conformity and social order in society (Hustedde \& Ganowicz 2002). Based on this perspective, business communities that undertake CSR will need other institutions including the government to establish regulations which could address various problems in the implementation of CSR.

\section{Result}

\subsection{The Regulations of CSR in Indonesia}

This study found that Indonesia government has an important role by stipulating several laws or legislations to regulate the implementation of CSR activities of business communities in Indonesia. The initial legislation is Article 33 paragraph (3) of the Constitution of the Republic of Indonesia Year 1945 states that the land, the water and the natural resources contained therein shall be controlled by the State and exploited to the greatest benefit of the people. In particular, the obligation of business communities to conduct CSR has been started when Indonesia government welcomed foreign investors to undertake mining operations in Indonesia through a contract system known as Kontrak Karya (KK) or the Contract of Work $(\mathrm{CoW})$. The foreign investor should have commitment to deliver benefit to the community 
while exploit natural resources in Indonesia. This obligation was mentioned clearly after at fifth generation of the CoW. Furthermore, the government has stipulated laws or legislation to regulate the implementation of CSR of business communities in Indonesia. Included in these legislations are the Act Number 40 Year 2007 about Limited Corporate, in particular Article 74 and Article 74 Explanation deemed contradictory to Article 28D Paragraph (1), Article 28I paragraph (2) and the Constitutional Court Decision No. 53/PUU-VI/2008, stating that Article 74 paragraph (1), paragraph (2), and paragraph (3) of the Act Number 40 Year 2007 about Limited Corporate and its explanation is not contradictory to Article 28D Paragraph (1), Article 28I paragraph (2). Moreover, the CSR initiatives in the mining industries, specifically have been regulated under Mining Regulation UU No. 4/2009. In particular, article 95 states that one of compliances of mining companies is to conduct local community development.

Furthermore, there are also various legislations which have been stipulated by several ministries. For instance, The Ministry of Forestry has stipulated Peraturan Menteri Kehutanan (The Ministry of Forestry Regulation) No. 39 year 2013. It states that the business communities which have license to exploit forest products should deliver community development in partnerships programs with local communities. The same regulation related to the implementation of CSR has been promulgated by The Minister of Agriculture in Peraturan Menteri Pertanian Republik Indonesia (The Minister of Agriculture Regulation) No. 98 year 2013.

Based on aforementioned laws, the extractive industries in Indonesia are obliged to be responsible socially to their communities and environment where these industries are located. For instance, the Act Number 40 Year 2007 about Limited Corporate stated that companies' operation that related to natural resources exploitation are obliged to conduct CSR. It is also mentioned that sanctions would be applied if the regulations are not adhered to. This regulation has been compounded by the promulgation of ordinance on UU No. 25/2007 concerning investments in Indonesia. Chapter IX article 15 of this ordinance states that investors have an obligation to conduct CSR to local communities.

\subsection{The Local Government's Perception of CSR Activities}

This study found different perception of the local governments in perceiving the implementation of the CSR in the extractive industries in several provinces in Indonesia. First, there are local governments who perceive the extractive industries as partners to support the implementation of local government's development programs. The extractive industries have contributed by involving these programs in the implementation of their CSR activities, both infrastructure and capacity building programs. The partnership between the local governments and the extractive industries have been established to conduct several development programs on economic, education, health, religious activities, social, infrastructure, and youth as well as sport activities. For instance, CSR in the infrastructure programs are the building of schools and Pusat Kesehatan Masyarakat (Public Medical Centre) and other facilities such as mobile libraries dan Taman Baca Anak (Children Reading Centre). The extractive industries have also established capacity building programs such as funding for scholarships and medication for free, developing local business, training programs for midwives, and addressing malnutrition which have been suffered by many children.

Second, some local governments perceive the extractive industries as the development agents who could 'replace' their responsibility to deliver development programs to the local communities. The local governments argue that these industries should contribute towards the government's development programs not only in terms of the budget but also other resources needed for their implementation through their CSR activities. Third, the research studies, 
however, also show that some local governments neglect the CSR initiatives in the extractive industries. These local governments perceive that the only positive contribution of these industries is from their taxes. The local governments disregard the fact that the local communities surrounding the extractive industries areas have suffered from their operation. As a consequence, the affected local communities could not obtain maximum benefit from the extractive industries operations.

\section{Discussion}

The findings showed several roles of government in the implementation of CSR in the extractive industries. The most important role of government is by establishing various laws or legislations for CSR regulations. Under these regulations, the extractive industries in Indonesia have been forced to carry out CSR activities or community development programs to the affected local communities. The result of this study, however, showed that the stipulation of the CSR regulations has been challenged by several problems. This study found that there are various CSR regulations which have been established by Indonesian government at national level and in each department or ministry has specific laws or regulations related to CSR. Accordingly, the extractive industries should consider which regulations they have to choose to undertake their CSR initiatives.

This study found that there is lack of CSR regulations at local level to be employed by the local governments and the extractive industries in conducting CSR activities. This has caused several consequences. First, the extractive industries have designed their CSR activities without any guideline from certain regulations. The questions emerged in relation to the CSR of these industries including what kind of CSR activities that they should carry out and conducted and to what extend these industries should involve the local communities as well as the local governments in their CSR activities.

Second, insufficient guideline in the CSR activities creates different perception of the local governments related to the CSR of the extractive industries, determining to what extend the local governments should get involved in the implementation of CSR. The local governments who realize the importance of CSR will get involved and give more attention to its implementation. They will ensure the CSR of the extractive industries would minimize the negative impacts of these industries on as well as deliver much benefit for the local communities. These local governments would also require the extractive industries to involve the local communities in conducting their CSR. In contrast, some local governments who disregard the benefit of CSR do not realize that the affected local communities could get the benefit of CSR. It can be assumed that this kind of government could not become a mediator for both the extractive industries and the local communities when problems arise during the implementation of CSR.

\section{Conclusion and Recommendations}

This study shows that there is lack of the government involvement in the implementation of CSR in the extractive industries. The most important role of government mostly is mostly to stipulate various regulations which require the business communities, including the extractive industries in Indonesia to undertake CSR. In practice, however, there is insufficient guideline on how this CSR should be conducted at a local level. As consequences, the extractive industries have no guidelines on how to establish CSR activities, to what extend they should involve the local communities as well as the local governments in these activities and to address various problems which have emerged in the implementation of CSR. The extractive industries, moreover, have also been challenged by the contradictory agendas which 
are to obtain maximum profit from their operation and to be responsible socially to the affected communities. On the other side, the lack of guidelines in the CSR implementation at a local level has caused the local governments have different perception in relation to the CSR. As a result, the local governments have various takes on how to be involved in the CSR of the extractive industries

This study illustrates the complex problems which have emerged in the implementation of CSR in the extractive industries. Based on a structural functionalist perspective, these industries need other institutions including the government to establish policies or regulations as a guideline to determine the strategies by which they could address various problems in conducting the CSR. This study depicts that formal regulations at a national level related to CSR are not sufficient enough to become guidelines for the extractive industries to undertake CSR activities. Government, particularly local government needs to establish guideline at a local level to explain how these industries could undertake the CSR activities effectively. This is because the local government has the outmost understanding on the potential and the sociocultural backgrounds of the local communities that live in the surrounding of extractive industries.

\section{References}

[1] Ballard, C. (2001). Human Rights and the Mining Sector in Indonesia: A Baseline Study. International Institute for Environment and Development. Retrieved January Monday, 2020, from http://www.rimmrights.org/Documents/indonesia_hr_baseline.pdf

[2] Blowfield, M. (2004). CSR and Development: is Business Appropiating Global Justice? Development, 47, 61-68.

[3] Coronado, G., \& Fallon, W. (2010). Giving with one hand on the mining sector's treatment of indigenous stakeholders in the name of CSR. International Journal of Sociology and Social Policy, 30(11), 666-682. doi:DOI 10.1108/01443331011085259

[4] Francis, C., \& Baldesari. (2006). Systematic Reviews of Qualitative Literature. Oxford: UK Cochrane Centre.

[5] Frynas, J. G. (2005). The false developmental promise of Corporate Social Responsibility: evidence from multinational oil companies. International Affairs, 81(3), 581-598.

[6] Gilberthorpe, E., \& Banks, G. (2012). Development on whose terms?: CSR discourse and social realities in Papua New Guinea's extractive industries sector. Reosurces Policy, 37(2), 185-193. doi:https://doi.org/10.1016/j.resourpol.2011.09.005

[7] Guerra, M. C. (2002). Community Relations in Mineral Development Projects. The CEPMLP Internet Journal, 11, 1-31.

[8] Hb, G. (2011). Tanggung Jawab Sosial dan Lingkungan: sebuah Tanggung Jawab Moral atau Kewajiban Hukum (Putusan Mahkaman Konstitusi Nomor 53/puu-vi/2008). Jurnal Konstitusi, 4(02), 51-76.

[9] Hilson, G. (2012). Corporate Social Responsibility in the Extractive Industries: Experiences from Developing Countries. Resources Policy, 37(2), 131-137.

[10] Hilson, G., \& Murck, B. (2001). Progress Toward Pollution Prevention and Waste Minimization in the North American Gold Mining Industry. Journal of Cleaner Production, 9, 405-415.

[11] Jenkins, H., \& Obara, L. (2008). Corporate Social Responsibility (CSR) in the mining industry - the risk of community dependency. Corporate Responsibiity Research Conference (pp. 1-23). Belfast: Queen's Univesity Belfast. Retrieved from http://www.crrconference.org 
[12] Kemp, D. (2010). Mining and Community Development: Problems and Possibilities of Local Level Practice. Community Development Journal, 45(2), 198-218.

[13] Kitchenham, B. (2004). Procedures for Performing Systematic Reviews. Eversleigh: Keele University.

[14] Kolk, A. (2016). The Social Responsibility of International Business: From Ethics and the Environment to CSR and Sustainable Development. Journal of World Business, 51, 23-34. doi:10.1080/14754835.2015.1037953

[15] Korsah-Brown, D. (2002). Environment, Human Rights and Mining Conflict in Ghana. In L. Zarsky, Human Rights \& the Environment: Conflict and Norms in a Globalizing World (pp. 79-95). London: Earthscan Publications Ltd.

[16] Lesaffer, J., Ghys, F., Nguyen, V., \& Rouchon, J.-P. (2011). The CSR Challenges Facing the Extractive Industry in Weak Governance Zones: A Comparative Analysis of the Extractive Industry's Strategies and Performance on Human Rights, Community Involvement and Corruption in Weak Governance Zone. Casablanca: Transparence International France. Retrieved Febuary 4, 2020, from www.vigeo.com

[17] Lewin, S. (2008). Methods to Synthesise Qualitattive Evidence Alongside a Cochrane Intervention Review. London: London School of Hygiene and Tropical Medicine.

[18] MacKay, F. (2002). Mining in Suriname: Multionationals, the State and the Maroon Community of Nieuw Koffiekamp. In L. Zarsky, Human RIghts \& the Envirnment: Conflict and Norms in a Globalizing World (pp. 57-78). London: Earthscan Publication Ltd.

[19] Martin, S., \& Newell, K. (2008). Mining Ombudsman Case Report: Rapu-Rapu Polymetallic Mine. Carlton: Oxfam Australia.

[20] Muller, A. (2006). Global Versus Local CSR Strategies. European Management Journal, 24(2-3), 189-198. doi:https://doi.org/10.1016/j.emj.2006.03.008

[21] Newell, P., \& Frynas, J. (2007). Beyond CSR? Business, Poverty and Social Justice: an Introduction. Third World, 28(4), 669-681.

[22] Newell, P., \& Frynas, J. (2007). Beyond CSR? Business, Poverty and Social Justice: an Introduction. Third World Quarterly, 28(4), 669-681.

[23] Perry, A., \& Hammond, N. (2002). Systemic Review: The Experience of a Ph.D Student. Psychology Learning and Teaching, 2(1), 32-35.

[24] Ramasastry, A. (2015). Corporate Social Responsibility Versus Business and Human Rights: Bridging the Gap Between Responsibility and Accountability. Journal of Human Rights, 14(2), 237-259. doi:DOI: 10.1080/14754835.2015.1037953

[25] Rosenthal, E. (2002). Conflict Over Transnational Oil and Gas Development off Sakhalin Islan in the Russian Far East: A David and Goliath Tale. In L. Zarsky, Human Rights \& the Environment : Conflicts and Norms in a Globalizing World (pp. 96-119). London: Earthscan Publications Ltd.

[26] Sarin, R., Reisch, N., Kalafut, J., \& Slack, K. (2006). Tarnished Gold: Mining and the Unemt Promise Development. Eartworks, Bank Information Center, Oxfam America, Bretton Woods Project. Retrieved January 13th, 2020, from http://www.bicusa.org/en/Article.2956.aspx

[27] Siswanto. (2010). Systematic Review Sebagai Metode Penelitian Untuk Mensintesis Hasil-hasil Penelitian (Sebuah Pengantar). Buletin Penelitian Sistem Kesehatan, 13(4), 326-333.

[28] Siswanto. (2010). Systematic Review Sebagai Metode Penelitian Untuk Mensintesis Hasil-Hasil Penelitian (Sebuah Pengantar). Buletin Penelitian Sistem Kesehatan, 13(4), 326-333. 
[29] WHO. (2004). World Report on Knowledge for Better Health, Strengthening Health System. Geneva: World Health Organization.

[30] World, B. (2011). Breaking New Ground: Mining, Minerals and Sustainable Development. International Institute for Environment and Development. Retrieved January 14, 2020, from http://pubs.iied.org/9084IIED.html

[31] Yakovleva, N. (2005). Corporate Social Responsibility. England: Ashgate Hampshire. 